\title{
Tool Flank Wear Analysis for MQL Assisted Milling of Strenx 1100 Structural Steel
}

\author{
Mustafa Kuntoğlu ${ }^{1 *}$ \\ 1* Selcuk University, Faculty of Technology, Departmant of Mechcanical Engineering, Konya, Turkey, (ORCID: 0000-0002-7291-9468), mkuntoglu@ @elcuk.edu.tr
}

(First received 17 May 2021 and in final form 5 August 2021)

(DOI: $10.31590 /$ ejosat.938234)

ATIF/REFERENCE: Kuntoğlu, M. (2021). Tool Flank Wear Analysis for MQL Assisted Milling of Strenx 1100 Structural Steel. European Journal of Science and Technology, (25), 629-635.

\begin{abstract}
Strenx 1100 structural steel has unique material properties enables to utilize in important engineering applications such as marine and heavy vehicles. Due to the surface integrity of the parts produced by this material is of paramount importance, tool wear condition needs to be considered as well. As being applicable and easy to measure, tool flank wear $\left(V_{B}\right)$ is widely preferred in the field and reflects the remaining tool life. Minimum quantity lubrication (MQL) has been preferred most recently in machining operations especially for the hard-to-cut materials to improve the machinability characteristics. This paper contains experiments and further analysis of tool flank wear during MQL assisted milling of the Strenx 1100 steel. Cutting speed, feed rate and depth of cut were included in the experimental plan and Taguchi $\mathrm{L}_{9}$ design was adopted. Measured wear results were evaluated with $3 \mathrm{~d}$ surface plots, analysis of variance (ANOVA) and optimization of parameters were carried out depend on signal to noise $(\mathrm{S} / \mathrm{N})$ ratio. Accordingly, cutting speed is the first parameter affecting tool flank wear about $53.2 \%$ and followed by feed rate about $35.77 \%$. Parametric optimization depend on $\mathrm{S} / \mathrm{N}$ ratio shows that first order of theall cutting parameters need to be selected for minimum tool flank wear which is observed on $3 \mathrm{~d}$ graphs that the increase in the amount of wear with higher parameter levels. This comprehensive analysis is a guide for the practical applications in the industry as providing the limitations during applying a wide range of cutting parameters.
\end{abstract}

Keywords: Strenx 1100 Steel, Tool flank wear, MQL, Milling, Hard Machining.

\section{Strenx 1100 Yapısal Çeliğinin MMY Destekli Frezelenmesinde Serbest Yüzey Aşınması Analizi}

$\ddot{O} \mathbf{z}$

Strenx 1100 yapısal çeliği, deniz araçları ve ağır araçlar gibi önemli mühendislik uygulamalarında kullanılmasına olanak sağlayan benzersiz malzeme özelliklerine sahiptir. Bu malzemeden üretilen parçaların yüzey bütünlüğü büyük önem taşıdığından, takım aşınma durumunun da dikkate alınması gerekir. Uygulanabilir ve kolay ölçülebildiği için, takım serbest yüzey aşınması ( $\mathrm{V}_{\mathrm{B}}$ ) bu alanda yaygın olarak tercih edilir ve kalan takım ömrünü yansıtır. İşlenebilirlik özelliklerini iyileştirmek adına özellikle kesilmesi zor malzemeler için son zamanlarda işleme operasyonlarında minimum miktarda yağlama (MQL) uygulanmaktadır. Bu çalışma Strenx 1100 çeliğinin MMY destekli frezelemesi sırasında serbest yüzey aşınması analizini ve deneylerini içerir. Kesme hızı, ilerleme ve talaş derinliği deneysel plana dâhil edilmiş ve Taguchi $\mathrm{L}_{9}$ tasarımı benimsenmiştir. Ölçülen aşınma sonuçları 3 boyutlu yüzey grafikleri ile değerlendirilmiş, varyans analizi (ANOVA) ve parametrelerin optimizasyonu sinyal / gürültü (S / N) oranına bağlı olarak gerçekleştirilmiştir. Buna göre, kesme hızı serbest yüzey aşınmasını yaklaşık\% 53.2 oranında etkileyen ilk parametredir ve bunu yaklaşık \% 35.77 ile ilerleme izlemektedir. S / N oranına bağlı parametrik optimizasyon, minimum serbest yüzey aşınması için kesm parametrelerinin birinci sırasının seçilmesi gerektiğini göstermektedir. Bu kapsamlı analiz, çok çeşitli kesme parametrelerinin uygulanması sırasında sınırlamaları ortaya koyduğu için endüstrideki pratik uygulamalar için bir kılavuz niteliğindedir.

Anahtar Kelimeler: Strenx 1100 Çeliği, Serbest Yüzey Aşınması, MMY, Frezeleme, Sert işleme.

\footnotetext{
* Corresponding Author: mkuntoglu@ selcuk.edu.tr
} 


\section{Introduction}

Structural steels are generally preferred for their improved properties in load bearing applications. This type of steel requires good weldability in order to create large scale parts utilized for transportation. However, additional machining operation needs to be performed for manufacturing of welding grooves. Strenx 1100 is a member of the structural steel family characterized with high tensile and yield strength which makes it appropriate in many sector such as marine engineering, excavators, heavy vehicles and cranes (Kurc-Lisiecka, Piwnik, \& Lisiecki, 2017; SSAB, 2021). Beyond its explicit advantages, Strenx 1100 can be accepted as hard-to-cut material with ingredients and mechanical properties. Typically, due to their sheet-metal form, several modifications can be performed by milling operation for industrial applications.

Hard materials have been demanded growingly from the industries especially in the last decade (Davim, 2011; Grzesik, 2008). Compared to conventional materials, they present challenging issues such as poor surface integrity and excessive tool wear (Umbrello, Micari, \& Jawahir, 2012). The problem is originated from high cutting forces and temperatures at the cutting area (Tönshoff, Arendt, \& Amor, 2000). The cutting tool is experienced surplus mechanical and thermal loads primarily that pave the way for rapid deformations. Since the machined surface is of paramount importance (Şahinoğullari \& Luş, 2021), cutting edge needs to be considered at least that much (Niaki \& Mears, 2017). To date, some attempts have been made with taking precautions to overcome these problems (Chandrasekaran \& M'Saoubi, 2006). MQL assisted machining is a known and effective way which conveys the pulverized oil to the cutting zone with the help of pressured air (Dong \& Duc, 2019; Sen, Mia, Mandal, \& Mondal, 2019). Oil granules make easier to separate the chip from main material with decreasing the coefficient of friction when it is compared with dry cutting conditions (Çetindağ, Çiçek, \& Uçak, 2020). Therefore, cutting forces and temperatures are reduced considerably. This procures to achieve longer cutter life, less energy consumption and sustainable machining environment (Bermingham, Sim, Kent, Gardiner, \& Dargusch, 2015; Jang, Jung, \& Seok, 2016). Toward flood cooling, MQL allows for employing minimum fluid which reduces environmental and economic burden as well (Gupta et al., 2021). By this way, adverse effect of the chemicals in the lubricants can be avoided for the humans, nature and living creatures. MQL technology has been integrated to different machine tools successfully from many researchers in the past for the mentioned advantages and contributions.

The literature review shows that a plenty of paper published were focused on the improvements obtained by MQL. A group of them have been studied about the tool wear and related mechanisms before during hard milling operation. Mia worked on the milling of AISI 4140 with MQL for optimum conditions and they stated the deviation in surface quality was revealed owing to the flank wear (Mia, 2018). Muaz and Choudhury carried out a study on experimental investigation of milling of AISI 4340 steel comparing lubrication strategies (Muaz \& Choudhury, 2019). On another study, MQL adopted hard milling of AISI D2 was modeled for measuring effectiveness of parameters in order to determine tool life (Iqbal, Ning, Khan, Liang, \& Dar, 2008). A performance measurement was performed based on different ingredients of MQL during milling of Hastelloy C276 (Günan, Kıvak, Yıldırım, \& Sarıkaya, 2020). The best tool life was determined according to cooling strategy along with tool wear types and triggering mechanisms. Zhang et al. investigated tool wear mechanisms during milling of hard H13 steel under different cooling environments (Zhang, Li, \& Lv, 2014). Bashir et al. indicated the optimum cooling conditions in order to achieve longer tool life and machining characteristics for hardened AISI 4140 steel (Al Bashir, Mia, \& Dhar, 2018). They exhibited the supremecy of MQL system clearly on obtaining better tool life. A comparative study was carried out for the best oil mixtures during MQL based hard milling of Inconel 690 (Sen, Gupta, Mia, Pimenov, \& Mikołajczyk, 2021). The best tool wear and machinability conditions were reached by palm and castor oil. Najiha and Rahman compared flood and MQL conditions during end milling of aluminum alloy. A detailed tool wear analysis and flank wear evaluation was performed and showed the benefits of MQL employment (Najiha \& Rahman, 2016). A MQL assisted end milling operation modeling study was proposed from the authors (Sen, Mia, Mandal, Dutta, \& Mondal, 2019) which showed the possibility of high accuracy prediction of tool flank wear and a group of machining variables. Singh et al. applied evolutionary techniques for wear optimization in milling of Inconel 718 (Singh, Gupta, Mia, \& Sharma, 2018). It was a comparison study based on different cooling conditions which demonstrated the effectiveness of MQL over other techniques. Seemingly, a plenty of paper published on the flank wear analysis using several workpiece materials in MQL assisted milling operation in the past. A general comment made about these papers on the superiority and effectiveness of MQL technique.

Although there have been a number papers on hard milling with MQL assistance, no paper was encountered focused on the sustainable milling of Strenx 1100 construction steel. Therefore, this paper aims to investigate the tool flank wear progression. Data analysis were carried out with $3 \mathrm{D}$ surface plots, $\mathrm{S} / \mathrm{N}$ ratio based optimization and ANOVA.

\section{Material and Method}

\subsection{Material Properties}

The workpiece utilized in the experiments is a special type of structural steel titled as Stenx 1100. Test materials are appropriate for milling operations provided by the manufacturer. Thus, chemical composition and mechanical properties can be procured $(S S A B, 2021)$. Table 1 and Table 2 listed these properties separately. The dimensions of the samples (32 HRC) were $100 \times 100 \times 40 \mathrm{~mm}$. To meet the requirements of standard experiments, fresh cutting tools were used for each test. Tool holder with the code 403 BT 40 ER32 x 70 (MAS) and cutting tool inserts with the code number of APXT 1604 PDSR-MM TIN (KORLOY) were chosen. 


\begin{tabular}{c|c}
\hline Elements & Amounts \\
\hline $\mathrm{C}$ & 0.21 \\
\hline $\mathrm{Si}$ & 0.5 \\
\hline $\mathrm{Mn}$ & 1.4 \\
\hline $\mathrm{P}$ & 0.02 \\
\hline $\mathrm{S}$ & 0.005 \\
\hline $\mathrm{Cr}$ & 0.8 \\
\hline $\mathrm{Cu}$ & 0.3 \\
\hline $\mathrm{Ni}$ & 3 \\
\hline $\mathrm{Mo}$ & 0.7 \\
\hline $\mathrm{B}$ & 0.005
\end{tabular}

\subsection{Machine Tool Properties and Physical Tests}

Cutting speed, feed rate and depth of cut were defined in the experiments. Physical tests were done on CNC (DAHLIL). Instead of 27 experiments, Taguchi design was used and totally 9 physical tests were performed which is explained in following. Before the experiments, some observations during preliminary tests helped for determination of final values. In this procedure, a number of initial parameters were approved considering chatter vibrations and undesired chip formation. All of the experiments were executed as three times and eventually the arithmetic average value was calculated.

\subsection{MQL System}

MQL supply was fed from the depository unit (Werte) having $24 \mathrm{~V}$ AC/DC voltage and 4 bars pressure. For the lubrication, KT 2000 oil was utilized and conveyed to the machine environment and nozzle $50 \mathrm{ml} / \mathrm{h}$ with the amount of lubrication in unit time. Nozzle placement was arranged closely to the cutting area targeting the contact zone. MQL nozzle adopte to the machine tool is demonstrated in Figure 1.

\subsection{Experimental Design}

Due to the high material wastage and high costs of the utilized material, Taguchi based experimental design is capable of limiting the extreme consumes (Taguchi, 1987). Main purpose of this method is to provide minimum number of experiments according to the selected parameters group in the pool. Taguchi is an approved method used for optimization and experimental design (Kivak, 2014). Typically, Taguchi reduces extra costs, labor and time within the purpose of high quality and efficiency. This also achieves minimum energy consumption and wastage which pave the way for sustainable manufacturing. In this work, in place of all experiments, $\mathrm{L}_{9}$ orthogonal array was utilized. Taguchi based experimental design is exhibited in Table 3 which contains the adopted parameters as well.

\begin{tabular}{c|c|c}
\hline $\begin{array}{c}\text { vc } \\
\text { Cutting } \\
\text { Speed } \\
(\mathbf{A})\end{array}$ & $\begin{array}{c}\mathbf{f} \\
\text { Feed } \\
\text { Rate } \\
(\mathbf{B})\end{array}$ & $\begin{array}{c}\text { ap } \\
\text { Depth } \\
\text { of Cut } \\
(\mathbf{C})\end{array}$ \\
\hline 75 & 0.075 & 0.25 \\
\hline 75 & 0.15 & 0.5 \\
\hline 75 & 0.225 & 0.75 \\
\hline 150 & 0.075 & 0.5 \\
\hline 150 & 0.15 & 0.75 \\
\hline 150 & 0.225 & 0.25 \\
\hline 225 & 0.075 & 0.75 \\
\hline 225 & 0.15 & 0.25 \\
\hline 225 & 0.225 & 0.5 \\
\hline
\end{tabular}

Taguchi addresses two main operational function namely $\mathrm{S} / \mathrm{N}$ ratio and objective function. Taguchi aims to reduce noises in order to reach minimum number of tests simultanously. Also, for determination of performance of the targeted responses, standart deviations are calculated using objective function (Kechagias, Aslani, Fountas, Vaxevanidis, \& Manolakos, 2020). According to the demand from the target response, some equations are used for determination of the optimum value which can be maximization, minimization or normalization (Kuntoğlu \& Sağlam, 2019). Due to the expectation from the wear development is as low as possible, smaller is better type objective function needs to be calculated as demonstrated in the following equation:

$$
\mathrm{S} / \mathrm{N}=-10 \log \left[\frac{1}{x} \sum_{i=1}^{x} z_{i}^{2}\right]
$$

\subsection{Tool Flank Wear Measurement}

The flank wear expands on the tool surface in vertical and horizontal directions. Wear depth is the main determinative of the severeness level (Siddhpura \& Paurobally, 2013). Since the propagation may fluctuate on the area, either maximum depth or average depth is taken as the flank wear value. In this paper, former one was chosen as the main tool wear. Flank wear measurements were obtained on microscope (Leika) after each experiment. Figure 1 represents the measuring of the flank wear with macro and micro photos of cutting edge. Also, machine tool and MQL system are represented as an experimental image. After the measurement of wear, detailed analyses were performed as it will be explained in the next section.

\section{Results and Discussion}

Tool flank wear is accepted as the main tool life criteria as develops intersection of the main cutting edge and flank surface ("ISO 3685-1993(E). Tool life testing with single point turning tools," 1993). With higher wear values at this area, tool loses its cutting ability which leads to higher cutting forces and cutting tool geometry changes. In addition, chatter vibrations may show it as a result of the variable cutting conditions. With the progression of this type of wear, other wear types may be triggered resulting in the failure of cutting edge.

Figure 2 demonstrates the flank wear conditions on the flank surface for 9 experiments. Except for the flank wear, other wear 
types were not observed clearly. All measurements have been taken with the same zoom rate and lightness in order to protect

the safety of the measurements.
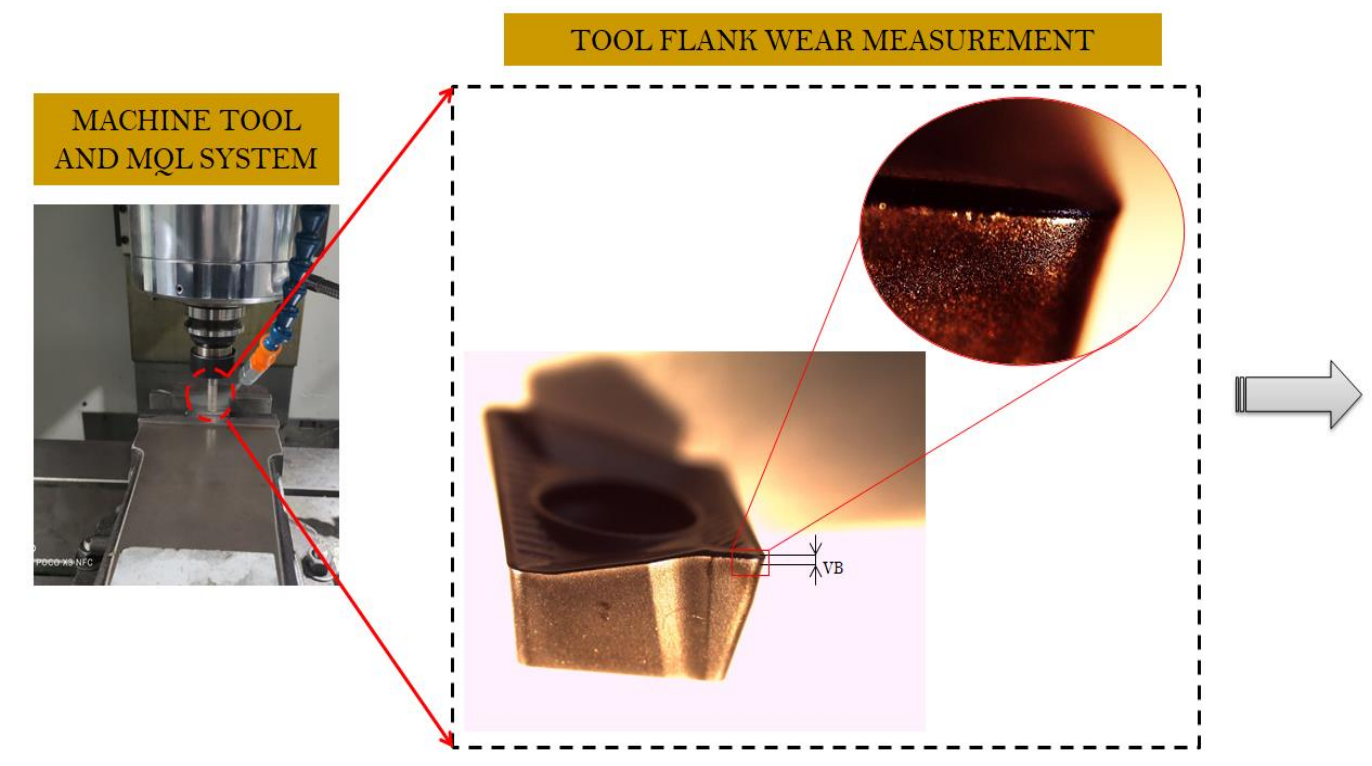

\section{TOOL WEAR ANALYSIS}
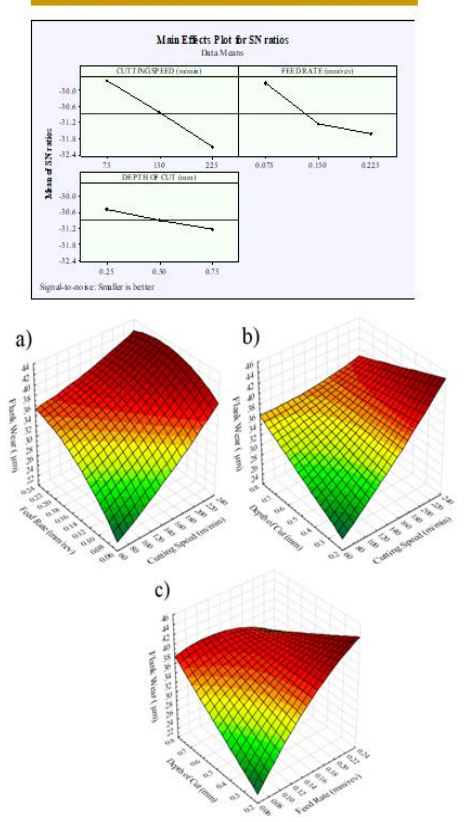

Figure 1. Measuring of flank wear and graphical abstract

\subsection{Tool Wear Mechanism}

As being a natural event, tool wear develops on the cutting tool during metal removing as a result of load factors such as mechanical, thermal, chemical and oxidation (Coromant, 1994; Kuntoğlu \& Sağlam, 2019). According to different areas of the cutting tool edge, each factor is effective depend on the occurring mechanism. It is actually depend on the contact area between tool and workpiece, chips formation, temperature gradient, stress distribution and ingredients of the materials. As a result, four different types of wear mechanisms reveal while machining. Abrasive, adhesive, diffusion, oxidation and fatigue wear may occur separately or together. Flank wear is attributed to the abrasive and adhesive wear mechanisms primarily (Aslan, 2020). Abrasive wear is characterized as the hard particles ruptured from the cutting tool and workpiece abrade the cutting face with squeezing between tool and workpiece during chip removing. Adhesive wear on the other hand is triggered by the cohesion of the soft particles of workpiece to the cutting tool and bring along the tool material during rupturing from the material.

\subsection{3d Surface Plot Based Analysis}

Basically, tool life is an important representative when determining the total costs of a manufacturing chain. Despite there are many contributing factors from beginning the material supply to the assembly process, tool condition is an effective variable with its hidden and open impacts. Owing to the importance of cutting geometry, whole cutting procedure is affected from the wear situation of the cutting tool. But the main concern should be the part quality which heavily depends on the tool health. Therefore, progressive flank wear need to be considered for the success of the cutting process.

Figure 3 demonstrates the 3D surface plots for the combined effect of of cutting parameters on flank wear during milling of Strenx 1100 steel. During cutting of hard materials, difficult-tocut and high strength structure requires high cutting forces.
However, compelling the chip to separate from the main material leads to high cutting temperatures, unstable stress distribution and on the next cycles accelerates tool wear progression. High cutting speeds make easier chip removing and increases coefficient of friction at the same time. In the context of this study, MQL assistance prohibited the rapid increase of flank wear as it can be seen in the Figure 3a-c. Considering the upper limit of the flank wear is about $0.2 \mathrm{~mm}$ in general, maximum wear land was observed in the range of 22-46 $\mu \mathrm{m}$.

In Figure 3a, cutting speed and feed rate with high values increases up the flank wear value dramatically to the boundary conditions. It was also found from the authors (Sen, Mia, Mandal, Dutta, et al., 2019) in hard milling. Agreeing the feed rate is a kind of speed of the cutting tool, it is expected that higher feed rate and cutting speed elevate the cutting temperatures with the increase of friction.

When Figure $3 b$ is considered, the effect of higher values of cutting speed can be observed especially for the lower depth of cut values on the progression of flank wear. On the small cutting speed values, the change from 0.25 to $0.75 \mathrm{~mm}$ of depth of cut speed up the flank wear which is attributed to the high material removal rate. However, with the increase of cutting speed and especially for the maximum values, high depth of cut reduces flank wear rate (Astakhov, 2007). Considering the incluence of depth of cut compared to cutting speed, this reduction can be neglected.

For the Figure $3 c$, similar observations can be performed with the $3 \mathrm{a}$ and $3 \mathrm{~b}$ as cutting parameters exhibit the same behavior. However, it should be noted that dramatic impact of depth of cut is observed clearly compared to Figure $3 \mathrm{~b}$. It is thought that high cutting depth enables the contact of toolworkpiece materials which is important to keep the cutting geometry due to the hardness of the steel. Similar result was found from Sen et al. during milling of hard material (Sen, Mia, Mandal, Dutta, et al., 2019). Lower values may lead to loss of 
ideal cutting conditions and undesired chip form, unbalanced load distribution and cutting forces.
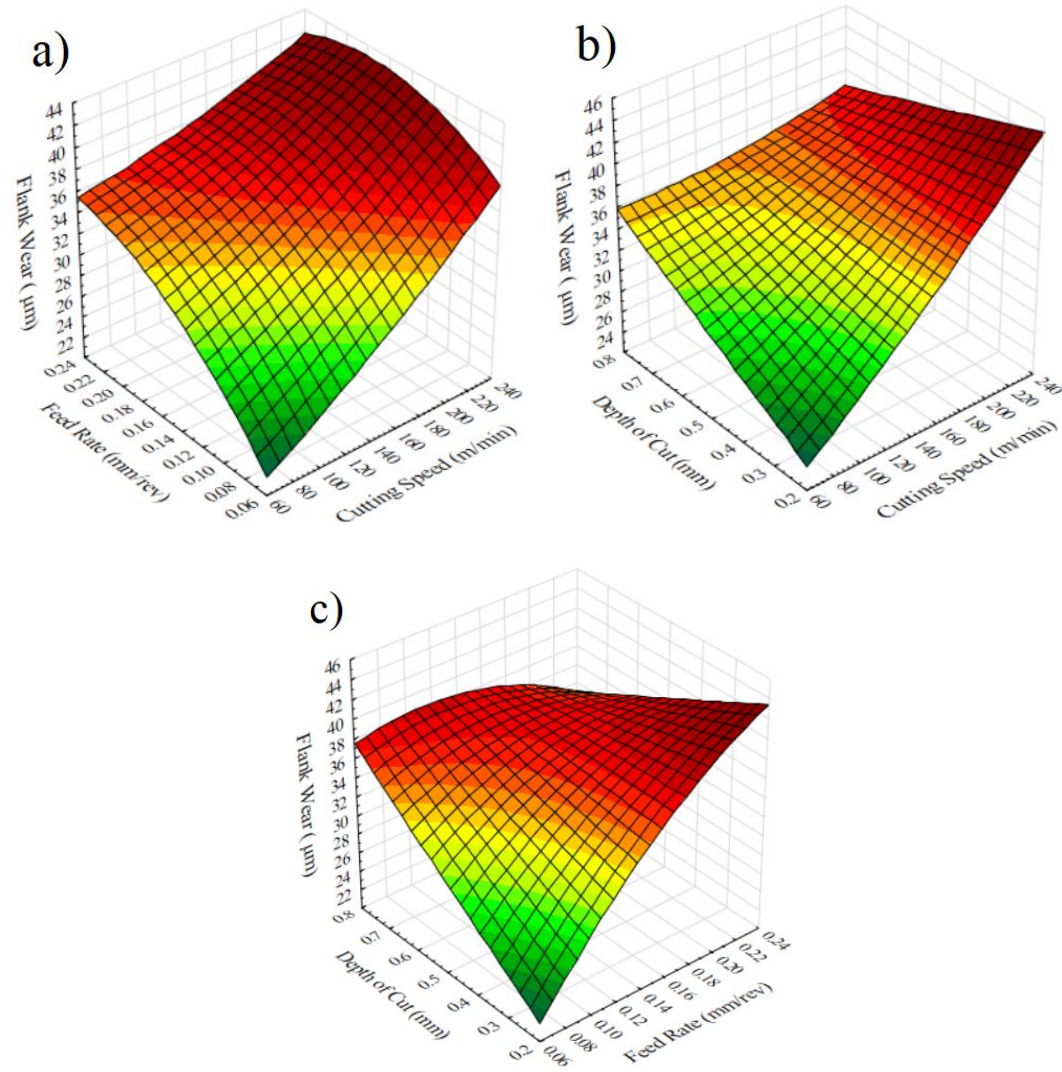

Figure 3. 3D plots of the combined effect of inputs on flank wear

\subsection{Parametric optimization for flank wear}

Parameter optimization is crucial step on data analysis. In addition, it is considerably determinative on the general performance of cutting tool. Thus, optimum conditions should be obtained for any response parameter in the way of better machinability.

Taguchi optimization is reliable and accepted method for determining the best milling parameters. In Figure 4, main effects plot for $\mathrm{S} / \mathrm{N}$ ratios are presented. Due to $\mathrm{S} / \mathrm{N}$ ratio is calculated with ratio of signal power to noise power, higher values are accepted as the best, in here the minimum value. As it can be seen, lower values of cutting speed, feed rate and depth of cut produce the best flank wear value $\left(\mathrm{v}_{\mathrm{C}}=75 \mathrm{~m} / \mathrm{min}, \mathrm{f}=0.075\right.$ $\mathrm{mm} / \mathrm{rev}, \mathrm{a}_{\mathrm{P}}=0.25 \mathrm{~mm}$ ). Accordingly $24.2 \mu \mathrm{m}$ is the minimum flank wear value in MQL assisted milling of Strenx 1100. In addition, it can be said that the questionable situation of depth of cut effect in 3D plots is clearly seen thanks to Taguchi based optimization.

\subsection{ANOVA for Flank Wear}

Anova provides the importance or the contribution rate of the design parameters on response parameter. Main advantage of this method is the several options for statistical measurement. Namely, statistical evaluation can be carried out by percent contribution (PC) which is calculated with dividing the sum squares (SS) of each parameter to the total SS value. Also, F value shows the impact and calculated with division of SS of parameters to the SS value of error. $\mathrm{P}$ value is a representative finding each parameter either they remain in the statistically important range in the $95 \%$ confidence interval.

When looking to the Table 5 for the Anova findings, PC value demonstrates that cutting speed is the most effective parameter about $53.2 \%$ and followed by feed rate which is influential about $35.77 \%$. Depth of cut has negligible importance on tool flank wear seemingly $(4.69 \%)$. F values also support these results $(8.39>5.64>0.74)$. Statistical findings verified the previous results as demonstrated in the $3 \mathrm{D}$ plots and Taguchi based optimization. Therefore, it is noteworthy to mention that a comprehensive analysis is performed for the optimization of milling conditions for flank wear of Strenx 1100 steel under MQL environment. 


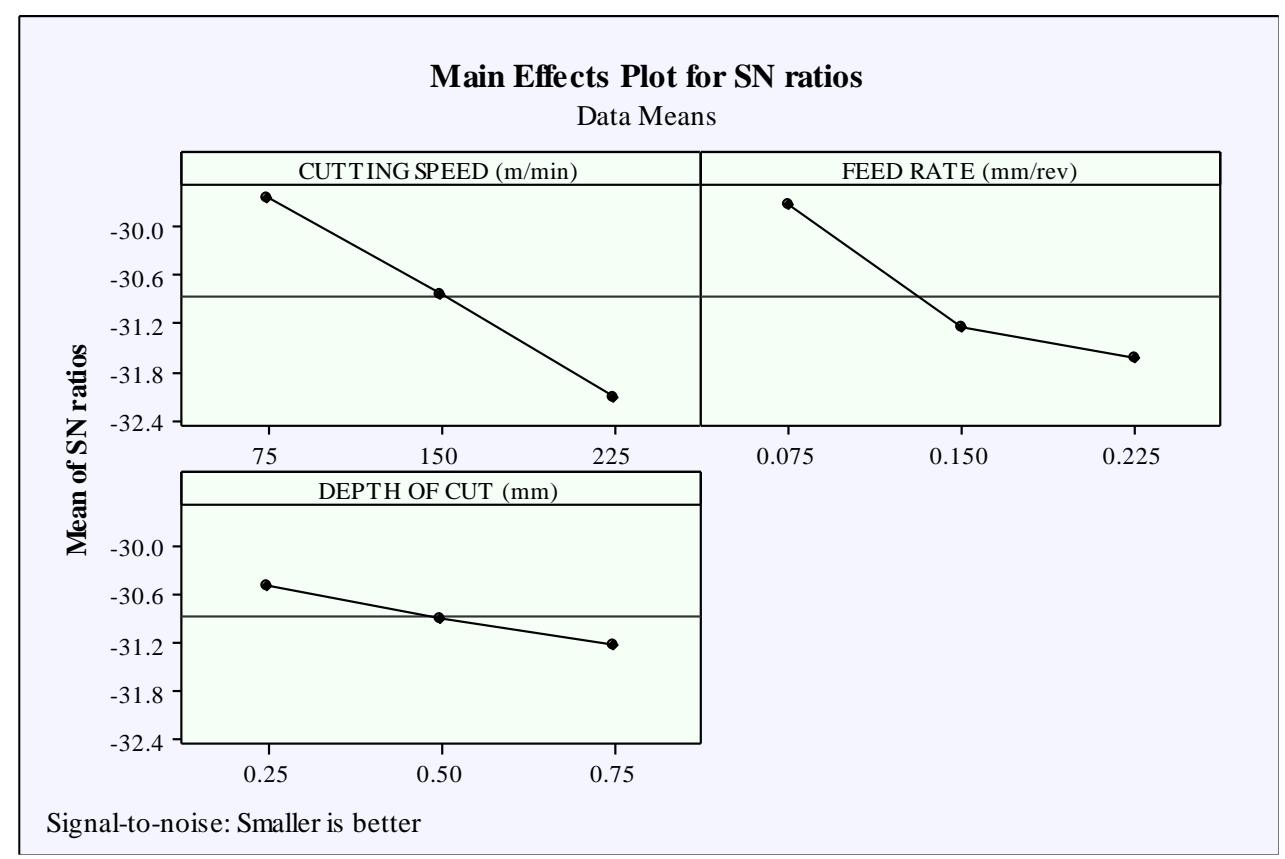

Figure 4. Optimum cutting parameters for minimum flank wear

Table 5. ANOVA results for flank wear

\begin{tabular}{c|c|c|c|c|c|c}
\hline Source & $\begin{array}{c}\text { Degree } \\
\text { of } \\
\text { Freedom }\end{array}$ & $\begin{array}{c}\text { Sequential } \\
\text { sums of } \\
\text { squares }\end{array}$ & $\begin{array}{c}\text { Adjusted } \\
\text { sums of } \\
\text { squares }\end{array}$ & $\begin{array}{c}\mathbf{F} \\
\text { value }\end{array}$ & $\begin{array}{c}\mathbf{P} \\
\text { value }\end{array}$ & $\begin{array}{c}\text { Percent } \\
\text { Contribution } \\
(\%)\end{array}$ \\
\hline Cutting Speed & 2 & 9.162 & 4.5810 & 8.39 & 0.106 & 53.2 \\
\hline Feed Rate & 2 & 6.1582 & 3.0791 & 5.64 & 0.151 & 35.77 \\
\hline Depth of Cut & 2 & 0.8081 & 0.4040 & 0.74 & 0.575 & 4.69 \\
\hline Residual Error & 2 & 1.0920 & 0.5460 & - & - & 6.34 \\
\hline Total & 8 & 17.2202 & - & - & - & 100 \\
\hline
\end{tabular}

\section{Conclusions and Recommendations}

A comprehensive analysis and evaluation for the construction steel, Strenx 1100 was carried out under MQL conditions during milling. Key findings from the study are summarized in the following:

- Cutting speed is the most effective parameter on flank wear with $53.2 \%$ contribution according to ANOVA which can be supported with $3 \mathrm{D}$ surface plots. Also, higher cutting speed produce higher flank wear which exhibits the minimum value of cutting speed should be selected for wear optimization.

- Feed rate follows the cutting speed in effectiveness with the contribution ratio of $35.77 \%$. It is also recommended that lowest feed rate value need to be considered for minimum flank wear.

- Seemingly, depth of cut has no important effect on flank wear.

- Minimum flank wear value can be obtained with the application of the group of cutting parameters namely, $\mathrm{v}_{\mathrm{C}}=75 \mathrm{~m} / \mathrm{min}, \mathrm{f}=0.075 \mathrm{~mm} / \mathrm{rev}, \mathrm{a}_{\mathrm{P}}=0.25 \mathrm{~mm}$.

- The outlined findings belong to ANOVA, 3D plots and optimization promote each other which demonstrate the validity of the selected methodology for the analysis of milling of Strenx 1100 construction steel.

- It can be concluded that the proposed method, evaluation with graphs, optimization plots and statistical analysis are compatible with each other and can be applied to hard milling operations.

- MQL assisted milling operations can be applied to several hard materials namely construction steels in the future considering their value in the industry.

\section{References}

Al Bashir, M., Mia, M., \& Dhar, N. R. (2018). Investigations on surface milling of hardened AISI 4140 steel with pulse jet MQL applicator. Journal of the Institution of Engineers (India): Series C, 99(3), 301-314.

Aslan, A. (2020). Optimization and Analysis of Process Parameters for Flank Wear, Cutting Forces and Vibration in Turning of AISI 5140: A Comprehensive Study. Measurement, 107959.

Astakhov, V. P. (2007). Effects of the cutting feed, depth of cut, and workpiece (bore) diameter on the tool wear rate. The 
International Journal of Advanced Manufacturing Technology, 34(7), 631-640.

Bermingham, M., Sim, W., Kent, D., Gardiner, S., \& Dargusch, M. (2015). Tool life and wear mechanisms in laser assisted milling Ti-6Al-4V. Wear, 322, 151-163.

Chandrasekaran, H., \& M'Saoubi, R. (2006). Improved machinability in hard milling and strategies for steel development. CIRP annals, 55(1), 93-96.

Coromant, S. (1994). Modern metal cutting: a practical handbook: Sandvik Coromant.

Çetindağ, H. A., Çiçek, A., \& Uçak, N. (2020). The effects of CryoMQL conditions on tool wear and surface integrity in hard turning of AISI 52100 bearing steel. Journal of Manufacturing Processes, 56, 463-473.

Davim, J. P. (2011). Machining of hard materials: Springer Science \& Business Media.

Dong, P. Q., \& Duc, T. M. (2019). Performance evaluation of MQCL hard milling of SKD 11 tool steel using MoS2 nanofluid. Metals, 9(6), 658.

Grzesik, W. (2008). Machining of hard materials. In Machining (pp. 97-126): Springer.

Gupta, M. K., Song, Q., Liu, Z., Sarikaya, M., Jamil, M., Mia, M., . . . Pimenov, D. Y. (2021). Environment and economic burden of sustainable cooling/lubrication methods in machining of Inconel-800. Journal of cleaner production, 287, 125074.

Günan, F., Kıvak, T., Yıldırım, Ç. V., \& Sarıkaya, M. (2020). Performance evaluation of MQL with AL2O3 mixed nanofluids prepared at different concentrations in milling of Hastelloy C276 alloy. Journal of Materials Research and Technology, 9(5), 10386-10400.

Iqbal, A., Ning, H., Khan, I., Liang, L., \& Dar, N. U. (2008). Modeling the effects of cutting parameters in MQLemployed finish hard-milling process using D-optimal method. Journal of materials processing technology, 199(13), 379-390.

ISO 3685-1993(E). Tool life testing with single point turning tools. (1993). In.

Jang, D.-y., Jung, J., \& Seok, J. (2016). Modeling and parameter optimization for cutting energy reduction in MQL milling process. International Journal of Precision Engineering and Manufacturing-Green Technology, 3(1), 5-12.

Kechagias, J. D., Aslani, K.-E., Fountas, N. A., Vaxevanidis, N. M., \& Manolakos, D. E. (2020). A comparative investigation of Taguchi and full factorial design for machinability prediction in turning of a titanium alloy. Measurement, 151, 107213.

Kıvak, T. (2014). Optimization of surface roughness and flank wear using the Taguchi method in milling of Hadfield steel with PVD and CVD coated inserts. Measurement, 50, 19-28.

Kuntoğlu, M., \& Sağlam, H. (2019). Investigation of progressive tool wear for determining of optimized machining parameters in turning. Measurement, 140, 427-436.

Kurc-Lisiecka, A., Piwnik, J., \& Lisiecki, A. (2017). Laser welding of new grade of advanced high strength steel STRENX 1100 MC. Archives of Metallurgy and Materials, 62.

Mia, M. (2018). Mathematical modeling and optimization of MQL assisted end milling characteristics based on RSM and Taguchi method. Measurement, 121, 249-260.

Muaz, M., \& Choudhury, S. K. (2019). Experimental investigations and multi-objective optimization of MQL- assisted milling process for finishing of AISI 4340 steel. Measurement, 138, 557-569.

Najiha, M. S., \& Rahman, M. (2016). Experimental investigation of flank wear in end milling of aluminum alloy with waterbased TiO 2 nanofluid lubricant in minimum quantity lubrication technique. The International Journal of Advanced Manufacturing Technology, 86(9), 2527-2537.

Niaki, F. A., \& Mears, L. (2017). A comprehensive study on the effects of tool wear on surface roughness, dimensional integrity and residual stress in turning IN718 hard-tomachine alloy. Journal of Manufacturing Processes, 30, 268-280.

Sen, B., Gupta, M. K., Mia, M., Pimenov, D. Y., \& Mikołajczyk, T. (2021). Performance Assessment of Minimum Quantity Castor-Palm Oil Mixtures in Hard-Milling Operation. Materials, 14(1), 198.

Sen, B., Mia, M., Mandal, U. K., Dutta, B., \& Mondal, S. P. (2019). Multi-objective optimization for MQL-assisted end milling operation: an intelligent hybrid strategy combining GEP and NTOPSIS. Neural Computing and Applications, 31(12), 8693-8717.

Sen, B., Mia, M., Mandal, U. K., \& Mondal, S. P. (2019). GEPand ANN-based tool wear monitoring: a virtually sensing predictive platform for MQL-assisted milling of Inconel 690. The International Journal of Advanced Manufacturing Technology, 105(1), 395-410.

Siddhpura, A., \& Paurobally, R. (2013). A review of flank wear prediction methods for tool condition monitoring in a turning process. The International Journal of Advanced Manufacturing Technology, 65(1-4), 371-393.

Singh, G., Gupta, M. K., Mia, M., \& Sharma, V. S. (2018). Modeling and optimization of tool wear in MQL-assisted milling of Inconel 718 superalloy using evolutionary techniques. The International Journal of Advanced Manufacturing Technology, 97(1), 481-494.

SSAB.

https://www.ssab.com.tr/api/sitecore/Datasheet/GetDocume nt?productId=6A0A9E9AF58C4AA2A29FC15CA0CE2590 \&language=en. .

Şahinoğullari, E., \& Luş, H. M. (2021). Effect of Machining on the Surface Roughness of 31CrMoV9 and 34CrAIMo5 Steels After Nitriding. Avrupa Bilim ve Teknoloji Dergisi(21), 410-415.

Taguchi, G. (1987). System of experimental design; engineering methods to optimize quality and minimize costs. Retrieved from New York, America:

Tönshoff, H., Arendt, C., \& Amor, R. B. (2000). Cutting of hardened steel. CIRP annals, 49(2), 547-566.

Umbrello, D., Micari, F., \& Jawahir, I. (2012). The effects of cryogenic cooling on surface integrity in hard machining: A comparison with dry machining. CIRP annals, 61(1), 103106.

Zhang, S., Li, J., \& Lv, H. (2014). Tool wear and formation mechanism of white layer when hard milling H13 steel under different cooling/lubrication conditions. Advances in Mechanical Engineering, 6, 949308. 